\title{
Epigallocatechin-3-gallate prevents TNF- $\alpha$-induced NF-кB activation thereby upregulating ABCA1 via the Nrf2/Keap1 pathway in macrophage foam cells
}

\author{
JIN JIANG ${ }^{1}$, ZHONG-CHENG MO ${ }^{1}$, KAI YIN ${ }^{1}$, GUO-JUN ZHAO ${ }^{1}$, YUN-CHENG LV ${ }^{1}$, XIN-PING OUYANG ${ }^{1}$, \\ ZHI-SHENG JIANG ${ }^{1}$, YUCHANG FU ${ }^{2}$ and CHAO-KE TANG ${ }^{1}$ \\ ${ }^{1}$ Institute of Cardiovascular Research, Key Laboratory for Atherosclerology of Hunan Province, Life Science \\ Research Center, University of South China, Hengyang 421001, P.R. China; ${ }^{2}$ Department of Nutrition \\ Sciences, University of Alabama at Birmingham, Birmingham, AL 35294-0012, USA
}

Received December 23, 2011; Accepted February 10, 2012

DOI: $10.3892 / \mathrm{ijmm} .2012 .924$

\begin{abstract}
The ATP-binding membrane cassette transporter A1 (ABCA1) plays a protective role in the development of atherosclerosis for the reverse cholesterol transport process. Epigallocatechin-3-gallate (EGCG), which exists abundantly in green tea, exerts an anti-atherosclerotic effect via antiinflammatory and metabolic regulation activities. Many genes and proteins related to lipid metabolism are involved in the lowering cholesterol effects of EGCG. However, effects of EGCG on ABCA1 have rarely been described. In the study presented here, we found that exposure of macrophage foam cells to TNF- $\alpha$ results in a downregulation of ABCA1 and a decrease in cholesterol efflux to apoA1, which is attenuated by pretreatment with EGCG. Moreover, rather than activating the Liver $\mathrm{X}$ receptor (LXR) pathway, inhibition of the $\mathrm{TNF}-\alpha$-induced nuclear factor- $\kappa \mathrm{B}(\mathrm{NF}-\kappa \mathrm{B})$ activity is detected with EGCG treatment in cells. In order to inhibit the $\mathrm{NF}-\kappa \mathrm{B}$ activity, EGCG can promote the dissociation of the nuclear factor E2-related factor 2 (Nrf2)-Kelch-like ECH-associated protein 1 (Keap1) complex; when the released Nrf2 translocates to the nucleus and activates the transcription of genes containing an ARE element inhibition of NF- $\mathrm{BB}$ occurs and Keap1 is separated from the complex to directly interact with $\mathrm{IKK} \beta$ and thus represses $\mathrm{NF}-\kappa \mathrm{B}$ function. These results provide novel insight into the anti-inflammatory effects of EGCG, as well as the identification of a novel potential therapeutic role for the prevention of atherosclerosis.
\end{abstract}

Correspondence to: Professor Chao-Ke Tang, Institute of Cardiovascular Research, University of South China, Hengyang, Hunan 421001, P.R. China

E-mail: tchaoke@yahoo.com.cn

Key words: atherosclerosis, epigallocatechin-3-gallate, ATP-binding membrane cassette transporter A1, Nrf2/Keap1 pathway, nuclear factor- $\kappa \mathrm{B}$

\section{Introduction}

Atherosclerosis is a disease characterized by inflammation, lipid accumulation and foam cell formation $(1,2)$. A wide range of inflammatory cytokines is produced by inflammatory cells, mainly macrophages and T-lymphocytes, in atherosclerotic lesions. The inflammation often leads to great alterations in some lipids, such as high-density lipoprotein (HDL) cholesterol, and lipoprotein metabolism, through altering the transcription of genes that controls lipid metabolism (3). HDL, however, plays a key role in protecting against atherosclerotic heart disease via reverse cholesterol transport ( $\mathrm{RCT}$ ), a process that delivers cholesterol from the arterial wall back to the liver for disposal (4-6). It is believed that RCT could be facilitated by a cell membrane protein called ATP-binding membrane cassette transporter A1 (ABCA1), mediating macrophage and other peripheral cellular free cholesterol efflux to extracellular HDL and/or lipid-free apolipoprotein AI (apoAI) $(7,8)$. The binding of free cholesterol to apoAI also leads to the generation of nascent HDL. Thus, it is clear that ABCA1 is critical for the synthesis of nascent HDL and plays a protective role in the development of atherosclerosis.

ABCA1 is a target gene for the Liver $\mathrm{X}$ receptor (LXR) which is a nuclear hormone transcription factor $(9,10)$. Targeting LXR activation is believed to enhance the expression of ABCA1 and remove cholesterol from the body (10-12). However, downregulation of ABCA1 has been observed following exposure to inflammatory stimuli including IL-1 $\beta$, TNF- $\alpha$, IFN- $\gamma$ and LPS, in which the nuclear factor- $\kappa \mathrm{B}$ $(\mathrm{NF}-\kappa \mathrm{B})$ dependent pathway was reported to be involved (13-16). Thus, inhibiting the NF- $\kappa \mathrm{B}$ pathway may be a mechanism for attenuating the downregulation of ABCA1 induced by an inflammatory stimulus.

Epigallocatechin-3-gallate (EGCG), which exists abundantly in green tea, has been shown to have some anti-carcinogenic, anti-oxidative, anti-proliferative and anti-mutagenic properties in animal models and cell studies (17-21). It is reported that a $67-\mathrm{kDa}$ laminin receptor $(67 \mathrm{LR})$, as the cell surface EGCG receptor, may be involved in mediating these actions of EGCG (22-25). Moreover, EGCG is also believed to exert an 
anti-atherosclerotic effect via anti-inflammatory and metabolic regulation activities $(26,27)$. It has also been proposed that EGCG could restrain inflammatory cytokines, such as TNF- $\alpha$ and IL-1 $\beta$, through blocking NF- $\kappa$ B pathway, and nuclear factor E2-related factor 2 (Nrf2) might be involved in this process $(18,28,29)$. Nrf2 is indispensable to cellular defense against many chemical insults of endogenous and exogenous origin, which plays a major role in the etiopathogenesis of many cancers and inflammation-related diseases (30). Under basal conditions, $\mathrm{Nrf} 2$ is sequestered by Kelch-like ECH-associated protein 1 (Keap1) in the cytoplasm leading to an enhanced proteasomal degradation of Nrf2. In conditions of oxidative stress, Nrf2 is released from Keap1 and translocates to the nucleus, thereby activating transcription of genes containing an ARE element in their promoter regions incurring a cytoprotective adaptive response (30). Thus, it raises the possibility that EGCG might play a role in upregulation of ABCA1, which is suppressed by inflammatory stimulus, via inhibition of NF- $\kappa \mathrm{B}$ translocation.

The present studies have been undertaken to investigate the possible effects and mechanisms of EGCG on ABCA1 in lipid loading and inflammatory macrophages. Our results have clearly demonstrated that, in THP-1 inflammatory macrophages, downregulation of ABCA1 is suppressed by TNF- $\alpha$-induced NF- $\kappa$ B translocation, and this inhibitory regulation of $\mathrm{TNF} / \mathrm{NF}-\kappa \mathrm{B}$ can be attenuated by EGCG via the Nrf-2/Keap1 pathway.

\section{Materials and methods}

Materials. Cell culture media and supplements were from Hyclone (South Logan, UT). Recombinant human apoAI were obtained from Protein Specialists (Prospec, Israel). CellTiter 96 AQueous One Solution Reagent was from Promega (Madison, WI). Lipofectamine ${ }^{\mathrm{TM}} 2000$ was from Invitrogen. LXR- $\alpha / \beta$, Keap1, Nrf2, NF-кBp65, IKK $\beta$, Lamin B2 and $\beta$-actin antibodies and histone $\mathrm{H} 1$ were obtained from Santa Cruz Biotechnology, Inc. (Santa Cruz, CA). ABCA1 antibody was purchased from Abcam (Abcam, UK). Epigallocatechin3-gallate (99\%), 5-aminoimidazole-4-carboxamide riboside (AICAR), 3-[4,5-Dimethylthiazol-2-yl]-2,5-tetrazoliumbromide (MTT), metformin, cholesterol (CHO) and other chemicals of reagent grade were purchased from Sigma Chemical (SigmaAldrich, MO).

Cell culture. Human THP-1 cells were cultured in RPMI-1640 supplemented with $0.1 \%$ non-essential amino acids, penicillin (100 U/ml), streptomycin $(100 \mu \mathrm{g} / \mathrm{ml})$, and $20 \%$ fetal bovine serum (FBS) at $37^{\circ} \mathrm{C}$ in $5 \% \mathrm{CO}_{2}$ at a cell density of 0.2 to $1.0 \times 10^{6} / \mathrm{ml}$. After 3-4 days, cells were treated with phorbol 12 -myristate 13 -acetate $(160 \mathrm{nmol} / \mathrm{l})$ for $12 \mathrm{~h}$, and then the medium was replaced by serum-free medium containing oxLDL $(50 \mu \mathrm{g} / \mathrm{ml})$ for $48 \mathrm{~h}$ to become fully differentiated macrophage foam cells. The cells were preincubated with or without different concentrations of EGCG for $16 \mathrm{~h}$ and then stimulated with TNF- $\alpha$ for either $2 \mathrm{~h}$ (mRNA studies) or $30 \mathrm{~min}$ (protein studies).

Cellular cholesterol efflux experiments. Cells were cultured as indicated above. Then they were labeled with $0.2 \mu \mathrm{Ci} / \mathrm{ml}$ $[3 \mathrm{H}]$ cholesterol. After $72 \mathrm{~h}$, cells were subsequently washed with phosphate-buffered saline (PBS) and incubated overnight in RPMI-1640 medium containing $0.1 \%(\mathrm{w} / \mathrm{v})$ bovine serum albumin (BSA) to allow equilibration of the $[3 \mathrm{H}]$ cholesterol in all of the cellular pools. Equilibrated $[3 \mathrm{H}]$ cholesterol-labeled cells were washed with PBS and incubated in $2 \mathrm{ml}$ of efflux medium containing RPMI-1640 medium, $0.1 \%$ BSA and $3 \mu \mathrm{g} /$ $\mathrm{ml}$ apoA1. A $150 \mu \mathrm{l}$ sample of efflux medium was obtained at the designated times and passed through a $0.45-\mu \mathrm{m}$ filter to remove any floating cells. The monolayers were washed twice in PBS, and cellular lipids were extracted with isopropanol. Medium and cell-associated $[3 \mathrm{H}]$ cholesterol was then measured by liquid scintillation counting. The percentage of efflux was calculated by the following equation: [total media counts/(total cellular counts + total media counts)] x100\%.

MTT (3-(4,5-dimethylthiazol-2-yl)-2,5-diplenyltetrazolium bromide) assay. A cell cytotoxicity assay was assessed by measuring the activity of mitochondrial dehydrogenase as described previously (31). THP-1 cells were plated in 96-well plates with a density of $1 \times 10^{4} /$ well. The medium was replaced after $24 \mathrm{~h}$. The cells were cultured as indicated above and then incubated with TNF- $\alpha(10 \mathrm{ng} / \mathrm{ml})$, or different concentrations $(10,20,40,80 \mu \mathrm{g} / \mathrm{ml})$ of EGCG, or $\mathrm{H}_{2} \mathrm{O}_{2}(100 \mu \mathrm{M})$, or control medium alone. After treatment for $24 \mathrm{~h}, 10 \mu \mathrm{l} /$ well of CellTiter 96 AQueous One Solution Reagent (MTT) was added. After incubation at $37^{\circ} \mathrm{C}$ for $1 \mathrm{~h}$ in a humidified $5 \% \mathrm{CO}_{2}$ atmosphere, the absorbance at $490 \mathrm{~nm}$ was recorded with an ELISA plate reader. Control refers to incubations in the presence of vehicle only ( $0.1 \%$ of DMSO or ethanol) and was considered to have $100 \%$ viable cells.

RNA estimation by real-time quantitative RT-PCR. mRNA levels were estimated by quantitative RT-PCR as described previously. The following primers were used to estimate human gene expression: ABCA1, forward, 5'-GTCCTCTTTCCCGCATTAT CTGG-3' and reverse, 5'-AGTTCCTGGAAGGTCTTGTT CAC-3'; LXR- $\alpha$, forward, 5'-GGTACAACCCTGGGAGTG AG-3' and reverse, 5'-TGGGGTTG ATGAATTCCACT-3'; LXR- $\beta$, forward, 5'-CGCTACAACCACGAGACAGA-3' and reverse, 5'-GGTTGATGAACTCCACCTGC-3'. These primers were designed using qPrimerDepot database. The values were normalized using $18 \mathrm{~S}$ rRNA as endogenous internal standard. The relative expression of the gene was calculated using comparative $\mathrm{CT}$ method (32). The followings are the qPCR Ct values for the respective genes: $18 \mathrm{~S}, 10$; ABCA1, 20; LXR- $\alpha, 23$; LXR- $\beta, 18$.

Western blot analyses. Protein (20 $\mu$ g lysates) was loaded on $80 \%$ SDS-polayacrylamide electrophoresis gel, electrophoresed for $2 \mathrm{~h}$ at $100 \mathrm{~V}$ in buffer, and transferred to polyvinylidene fluoride (PVDF) membranes. The primary antibodies were used against ABCA1, LXR $\alpha / \beta, \mathrm{Nrf} 2, \mathrm{NF}-\kappa \mathrm{B}$, Keap1, IKK $\beta$ and $\beta$-actin. Immunoreactivity was detected by ECL test. Protein content was calculated by densitometry using Labwords analysis software (32).

Transient transfection and luciferase reporter assay. Transfections were performed in 12-well plates with jetPEI reagent in THP-1 cells according to the manufacturer's instructions (Life Technologies). In the promoter activation studies, THP- 1 cells were cotransfected with $\beta$-galactosidase expression 
plasmid and the reporter plasmid of the hABCA1 [pABCA1 (-928)-luc] or hABCA1 [pABCA1 (-928 DR4 mut)-luc], a reporter construct which DR4 site was mutated. After $24 \mathrm{~h}$ of transfection, cells were treated with T0901317 (10 $\mu \mathrm{mol} / \mathrm{l})$, EGCG and/or TNF- $\alpha$, and then luciferase activities were measured with use of the Luciferase Assay system (Promega). The results were normalized against $\beta$-galactosidase.

Electrophoretic mobility shift assay (EMSA). EMSA was performed using double-stranded oligonucleotides (Promega) for the consensus binding site of the NF- $\mathrm{\kappa B}$ nucleotide (5'-AGT TGAGGGGACTTTCCCAGGC-3') and the consensus binding site of the ARE nucleotide (5'-CTACGATTTCTGCTTAGT CATTGTCTTCC-3'). Oligonucleotides were labeled in the following reaction: $2 \mathrm{ml}$ of oligonucleotide $(1.75 \mathrm{pmol} / \mathrm{ml})$, $2 \mathrm{ml}$ of $5 \mathrm{X}$ kinase buffer, $1 \mathrm{ml}$ of T4 polynucleotide kinase (10 U/ml) (Gibco Invitrogen, Barcelona, Spain), and $2.5 \mathrm{ml}$ of $\left[\gamma_{-}{ }^{32} \mathrm{P}\right]$-ATP $(3,000 \mathrm{Ci} / \mathrm{mmol}$ at $10 \mathrm{mCi} / \mathrm{ml})$ (Perkin Elmer, Waltham, MA), incubated at $37^{\circ} \mathrm{C}$ for $1 \mathrm{~h}$. The reaction was stopped by adding $90 \mathrm{ml}$ of TE buffer $(10 \mathrm{mM}$ Tris- $\mathrm{HCl} \mathrm{pH} 7.4$ and $1 \mathrm{mM}$ EDTA). To separate the labeled probe from the unbound ATP, the reaction mixture was eluted in a Nick column (GE Healthcare, CA) following the manufacturer's instructions. Eight micrograms of crude nuclear protein were incubated for $10 \mathrm{~min}$ on ice in binding buffer $(10 \mathrm{mM}$ Tris- $\mathrm{HCl}$ pH 8.0, $25 \mathrm{mM} \mathrm{KCl}, 0.5 \mathrm{mM}$ DTT, 0.1 mM EDTA pH 8.0,5\% glycerol, $5 \mathrm{mg} / \mathrm{ml} \mathrm{BSA}$, and $50 \mathrm{mg} / \mathrm{ml}$ poly (dI-dC), in a final volume of $15 \mathrm{ml}$. Labeled probe (approximately 60,000 cpm) was added and the reaction was incubated for $15 \mathrm{~min}$ at $4^{\circ} \mathrm{C}$ (NF- $\mathrm{kB})$. Where indicated, specific competitor oligonucleotide was added before the labeled probe and incubated for $10 \mathrm{~min}$ on ice. Normal rabbit IgG1 $(4 \mu \mathrm{g})$ was used as a control for the supershift assay. The mixtures were separated on native polyacrylamide gel and developed by autoradiography. The ${ }^{32} \mathrm{P}-$-labeled consensus sequence for OCT1 was used as a control for gel loading. Protein-DNA complexes were resolved by electrophoresis at $4{ }^{\circ} \mathrm{C}$ on a $5 \%$ acrylamide gel and subjected to autoradiography.

Small interfering RNA transfection. Cells were transfected with Nrf2 siRNA (600 nM), 67LR siRNA (600 nM) and Keap1 siRNA (600 nM) using Lipofectamine for $24 \mathrm{~h}$. After transfection, the cells were treated with EGCG $(24 \mathrm{~h})$ and TNF- $\alpha$ $(18 \mathrm{~h})$. The cells were then lysed for western blot analyses.

Statistical analysis. Data are presented as the mean and standard error. Statistical significance was analyzed by one-way ANOVA using the GraphPad Prism software (version 5.0). $\mathrm{P}$-value $<0.05$ was considered significant.

\section{Results}

TNF- $\alpha$ suppresses ABCAl transcription and decreases ABCA1-mediated cholesterol efflux, which can be attenuated by EGCG pretreatment. To address whether EGCG and/or TNF- $\alpha$ alters cholesterol efflux to apoA1, THP-1 macrophagederived foam cells were incubated with labeled cholesterol overnight. In cell culture dishes, EGCG and/or TNF- $\alpha$ or T0901317, an LXR agonist, were added to cell culture medium. ApoA1 was also added to the medium. After $18 \mathrm{~h}$ incubation, labeled cholesterol and cholesterol contents were measured. As shown Fig. 1A, compared with control cells incubated without EGCG and TNF- $\alpha$, the cholesterol efflux of cells exposed to TNF- $\alpha$ was markedly decreased; and the group of cells incubated with T0901317, the cholesterol efflux of cells was increased significantly. When compared with cells exposed to TNF- $\alpha$ alone, the cholesterol efflux of cells pre-incubated with EGCG $(40,80 \mu \mathrm{g} / \mathrm{ml})$ before exposure to TNF- $\alpha$ was modestly, but significantly, increased; and no significant differences were observed in these indicators studied between 40 and $80 \mu \mathrm{g} / \mathrm{ml}$, two different pretreatment concentrations of EGCG. Therefore, the $40 \mu \mathrm{g} / \mathrm{ml}$ of EGCG concentration was chosen for the following experiments. In addition, the cholesterol efflux of cells incubated with EGCG alone was altered insignificantly, when compared with the control cells. Thus, TNF- $\alpha$ decreased the efflux of cholesterol to apoA1, and this decreased effect of TNF- $\alpha$ could be attenuated by EGCG.

To investigate whether EGCG treatment can cause cell toxicity, effects of different concentrations of EGCG on foam cell viability were compared using MTT reagent. The differences in cell viability between different treatments were not statistically significant (Fig. 1B). These results indicated that the experimental concentrations (10 to $80 \mu \mathrm{g} / \mathrm{ml}$ ) of EGCG did not induce either cell proliferation or cell death.

To investigate if EGCG and/or TNF- $\alpha$ could alter the expression of ABCA1, cells were incubated with EGCG and/ or TNF- $\alpha$ for $18 \mathrm{~h}$. Following the incubation, ABCA1 mRNA levels were estimated by quantitative RT-PCR. Fig. 1C shows these results. It is clear from these data that TNF- $\alpha$ caused a decrease in ABCA1 mRNA levels, and EGCG pretreatment reduced the decrease effect of TNF- $\alpha$ in cells.

Next, the effect of EGCG and/or TNF- $\alpha$ on the activity of the ABCA1 promoter was also analyzed in our experiments. Cells were first transfected with the construct pABCA1 (-928)luc, a luciferase-expressing plasmid containing the ABCA1 promoter. Promoter activities of the construct pABCA1 (-928)-luc were then examined following incubation with EGCG and/or TNF- $\alpha$. The promoter activity of ABCA1 was markedly decreased in cells exposed to TNF- $\alpha$, and the EGCG pretreatment reduced the inhibitory effect of TNF- $\alpha$ (Fig. 1D). However, no significant differences were observed in the indicators studied between control cells and cells incubated with EGCG alone. Thus, these results suggested that the alteration of ABCA1 gene expression by EGCG and/or TNF- $\alpha$ depended on its transcription.

EGCG attenuates the effect of TNF- $\alpha$ on ABCA1 expression via inhibiting the $N F-\kappa B$ pathway rather than activating the LXR pathway. The cholesterol efflux of cells incubated with EGCG alone was altered insignificantly when compared with the control cells (Fig. 1A). However, the group of cells incubated with T0901317 was increased significantly, which raised the possibility that EGCG might have no effect on the LXR pathway. To further support the notion, the effect of EGCG and TNF- $\alpha$ on LXR- $\alpha / \beta$ was also examined. Cells were incubated with EGCG and/or TNF- $\alpha$ for $18 \mathrm{~h}$. Following incubation, mRNA levels for the respective genes were analyzed by real-time quantitative RT-PCR (Fig. 2A). In contrast to the marked alteration on ABCA1 gene expression, gene expression for LXR- $\alpha$ and LXR- $\beta$ were not affected by TNF- $\alpha$ and 
A
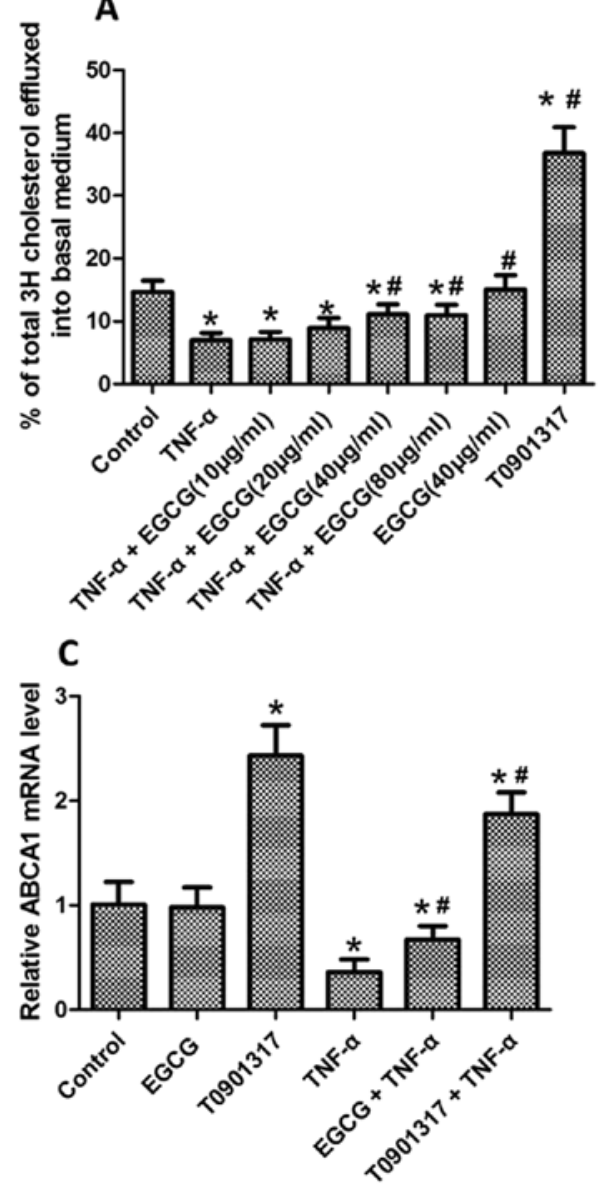

B

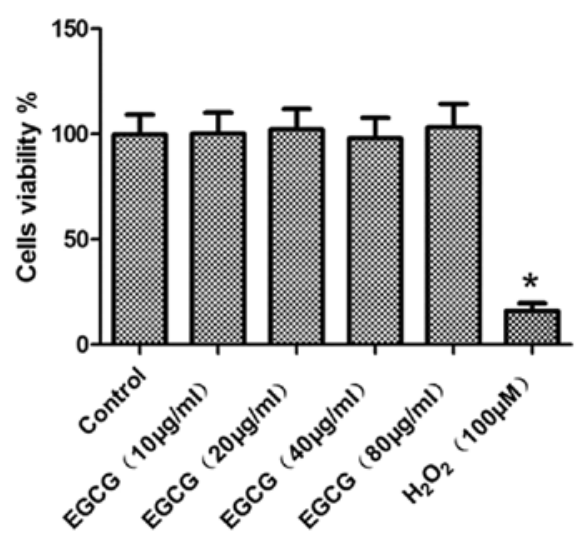

D

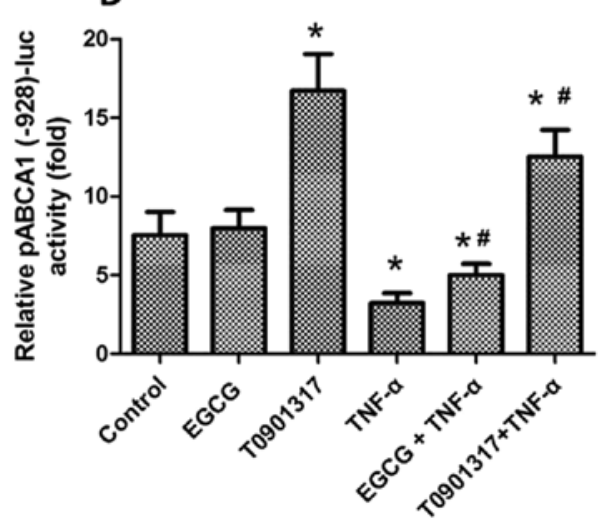

Figure 1. Effects of EGCG and/or TNF- $\alpha$ on the cholesterol efflux, ABCA1 gene expression and promoter activity. (A) Macrophage cells were cultured with labeled $[3 \mathrm{H}]$ cholesterol (concentration) for $24 \mathrm{~h}$ as described in the Material and methods. After washed to remove unincorporated radioactive cholesterol, cells were incubated with or without EGCG (concentration), TNF- $\alpha$ (concentration) and an LXR agonist T0901317 (10 $\mu$ mol/1) added to the medium. Then, ApoA1 was also added to the medium. Following $18 \mathrm{~h}$ incubation of these cells, the amount of labeled cholesterol recovered in the medium was analyzed as described in the Material and methods. (B) Macrophage cell viability was measured using CellTiter 96 Aqueous One Solution Reagent. Control (0 $\mu$ mol/1) refers to incubations in the presence of vehicle only (0.1\% DMSO) and was considered to have $100 \%$ viable cells. (C) Macrophage cells were incubated with EGCG (concentration) and/or TNF- $\alpha$ (concentration) for $18 \mathrm{~h}$. Following incubation, ABCA1 mRNA levels were examined by quantitative RT-PCR assays. (D) Macrophage cells were transfected for $24 \mathrm{~h}$ with $0.7 \mu \mathrm{g}$ pABCA1 (-928)-luc promoter plasmid. The cells were then incubated with EGCG and/or TNF- $\alpha$ T0901317 $(10 \mu \mathrm{mol} / \mathrm{l})$ for $18 \mathrm{~h}$, and promoter activity was analyzed as described in the Material and methods. Data are means \pm SE (repeated experiments; $\mathrm{n}=3) .{ }^{*} \mathrm{P}<0.05$ vs. control; ${ }^{\#} \mathrm{P}<0.05$ vs. TNF- $\alpha$.

EGCG. Furthermore, the protein levels of these genes were also studied, and the results were similar and no significant changes were detected in these experiments (Fig. 2B and C).

DR4 site located at the noncoding strand between -70 and $-55 \mathrm{bp}$ of the ABCA1 promoter is a sterol-responsive element regulated by $\mathrm{LXR}$ and RXR heterodimers. To confirm whether this DR4 sterol-responsive element is critical to TNF- $\alpha$ and EGCG treatments, cells were then transfected with the construct pABCA1-DR4M-luc, in which DR4 site was mutated. TNF- $\alpha$ and EGCG still altered the DR4 mutant promoter activities, but the effect of T0901317 on ABCA1 promoter activity was eliminated completely (Fig. 2D). These data suggest that TNF- $\alpha$ and EGCG altered the expression of ABCA1 in an LXR-independent manner.

A recent study has indicated that the $\mathrm{NF}-\kappa \mathrm{B}$ pathway plays a role in the inhibitory effect of TNF- $\alpha$ on ABCA1 expression in the human intestinal cell line Caco-2 (14). Thus in THP-1 foam cells, downregulation of ABCA1 expression by TNF- $\alpha$ may be acting through the $\mathrm{NF}-\kappa \mathrm{B}$ pathway, and the inhibition of TNF- $\alpha$-induced NF- $\kappa$ B activity may be involved in EGCG upregulating ABCA1. Therefore, we further examined the role of $N F-\kappa B$ pathway in TNF- $\alpha$-induced downregulation of ABCA1. Cells were incubated with or without TNF- $\alpha$, as well as AICAR and metformin, two individual inhibitors of the NF- $\kappa$ B pathway. Following incubation, ABCA1 mRNA and protein levels were determined. The two inhibitors of the NF- $\kappa \mathrm{B}$ pathway attenuated the inhibitory effect of TNF- $\alpha$ on ABCA1 gene and protein expression (Fig. 3A, B and C). These results suggest that the $\mathrm{NF}-\kappa \mathrm{B}$ pathway is involved in the inhibitory effect of TNF- $\alpha$ on ABCA1 expression in THP-1 macrophage foam cells.

To further demonstrate that EGCG could prevent TNF- $\alpha$ induced $\mathrm{NF}-\kappa \mathrm{B}$ activation, we next performed EMSAs for our cell treatment experiments. The labeled $\mathrm{NF}-\kappa \mathrm{B}$ probes formed two main complexes when incubated with cellular nuclear extracts (Fig. 3D). The specificity of the DNA-binding complexes was further assessed in competition experiments by adding an excess of unlabeled $\mathrm{NF}-\kappa \mathrm{B}$ oligonucleotide. When cells were exposed to TNF- $\alpha$, we detected the enhanced NF- $\kappa$ B DNA-binding activity in the EMSA assays, whereas the cells 
A

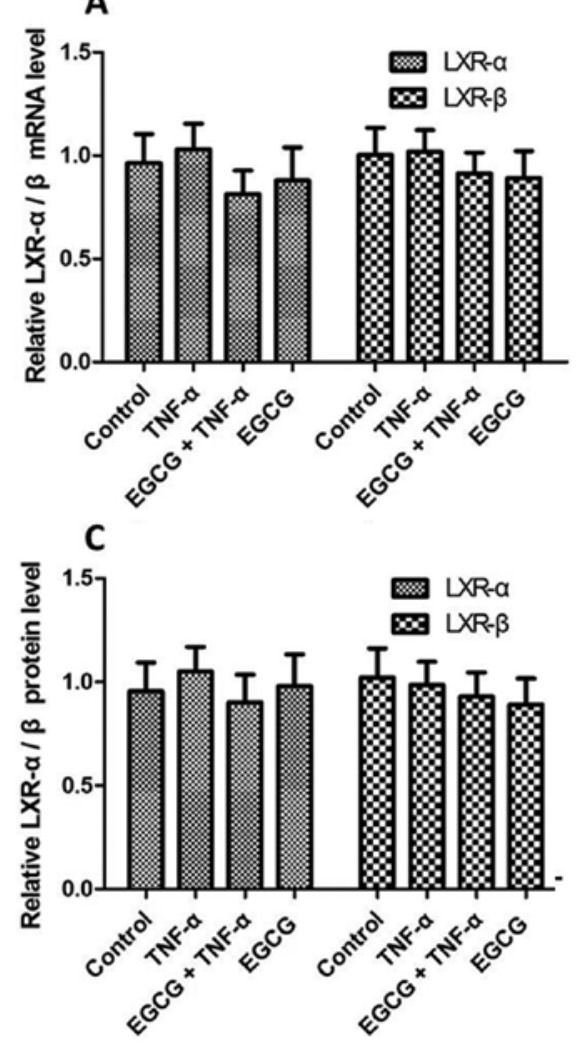

B

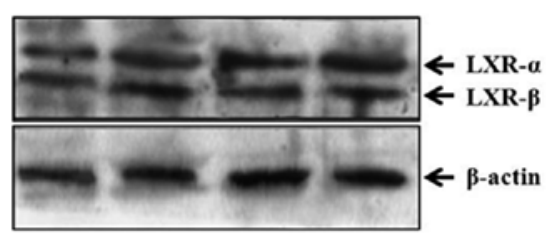

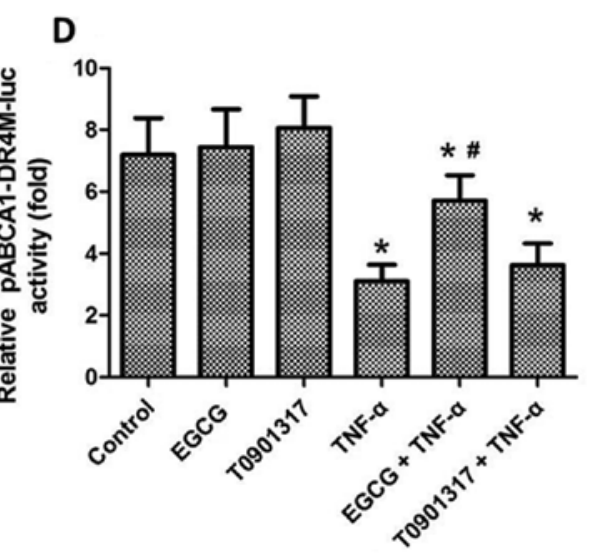

Figure 2. Effects of EGCG and/or TNF- $\alpha$ on LXR- $\alpha / \beta$. (A) Macrophage cells were incubated with TNF- $\alpha$, EGCG and T0901317 for 18 h. Following cell incubation, mRNA levels for the respective genes were examined by quantitative RT-PCRs. Following the incubation of cells, LXR- $\alpha$ and LXR- $\beta$ mRNA levels for these genes were analyzed by quantitative RT-PCRs. (B and C) LXR- $\alpha$ and LXR- $\beta$ protein levels were examined by western blot analysis. (D) Macrophage cells were transfected for $24 \mathrm{~h}$ with $0.7 \mu \mathrm{g}$ pABCA1 (-928)-luc promoter plasmid or pABCA1-DR4M-luc mutated promoter plasmid plus $0.2 \mu \mathrm{g}$ $\beta$-Gal expression plasmid as the experimental control and these cells were incubated with EGCG and/or TNF- $\alpha$ or T0901317 (10 $\mu$ mol/1) for 18 h, and the relative luciferase activities adjusted by $\beta$-Gal activities were then measured and analyzed. Data are means $\pm \mathrm{SE}\left(\mathrm{repeated}\right.$ experiments; $\mathrm{n}=3$ ). ${ }^{*} \mathrm{P}<0.05$ vs. control; ${ }^{\#} \mathrm{P}<0.05$ vs. TNF- $\alpha$.

pretreated with EGCG, our data showed a marked reduction in binding in the EMSA assays. Addition of antibody against the p65 subunit of NF- $\kappa \mathrm{B}$ reduced the intensity of these bands, whereas an unrelated antibody against $\mathrm{IgG1}$ did not, thereby indicating that EGCG attenuates the effect of TNF- $\alpha$ on ABCA1 expression via inhibiting the NF- $\kappa \mathrm{B}$ pathway.

EGCG prevents $T N F-\alpha$-induced $N F-\kappa B$ activation and upregulates ABCA1 through Nrf2/Keapl pathway. Previous studies have indicated the involvement of Nrf2-Keap1 signaling in EGCG enhanced antioxidant activities with subsequent restraints $\mathrm{NF}-\kappa \mathrm{B}$ activation $(18,28,29)$. The main function of $\mathrm{Nrf} 2$ is to activate the antioxidant response and induce transcription of a wide array of genes that is able to combat the harmful effects of oxidative stress and inflammation. The promoter regions of Nrf2 target genes contain a specific DNA sequence, called the antioxidant response element (ARE), which is required for Nrf2 binding and gene induction. Therefore, to demonstrate the effect of EGCG on Nrf2, we performed EMSA assays for our experiments. Cells exposed to TNF- $\alpha$ showed attenuated Nrf2 DNA-binding activity, whereas cells pretreated with EGCG showed enhancement in binding of Nrf2 (Fig. 4A). Addition of antibody against the Nrf2 reduced the intensity of these bands, whereas an unrelated antibody against IgG1 did not.
Nrf2 protein levels were also measured by western blot analysis. As the results in Fig. 4B and C show, low levels of nuclear Nrf2 were detected in control cells, while treatment with EGCG resulted in a great increase. Very few nuclear Nrf2 was detected in cells exposed to TNF- $\alpha$, and a significant increase was found in pretreatment with EGCG. Thus, these results might suggest that one of the main mechanisms involved in the down-regulation effect on $\mathrm{NF}-\kappa \mathrm{B}$ pathway and up-regulation effect on ABCA1 of EGCG is through its ability to induce Nrf2 translocation into nuclei and enhance the DNA-binding activity of Nrf2.

To further confirm these results, we knocked down 67LR and Nrf2 by siRNA experiments to study the effects of Nrf2 on the NF- $\kappa \mathrm{B}$ signaling pathway and ABCA1. Cells were transfected with 67LR siRNA and Nrf2 siRNA using Lipofectamine for $24 \mathrm{~h}$. Transfection effects were examined and analyze in these cells. Transfection of the Nrf2 siRNA and 67LR siRNA for gene knockdown successfully prevented the EGCG-induced increase at Nrf2 nuclear protein levels (Fig. 4D and E). Consequently, with the Nrf2 siRNA and 67LR siRNA transfection, the nuclear NF- $\kappa \mathrm{B}$ p65 protein levels were also examined and measured (Fig. 4F and G). With the 67LR siRNA transfection, the inhibited effects of EGCG at nuclear NF- $\mathrm{B}$ p 65 protein levels were completely abrogated. Interestingly, with the Nrf2 knocked down, the inhibition 
A
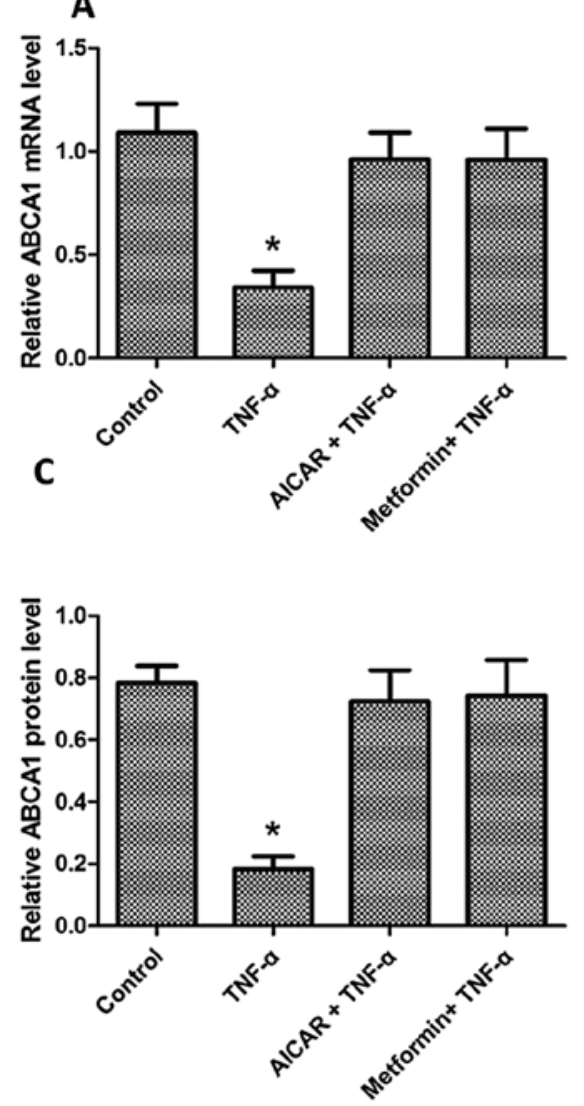

B

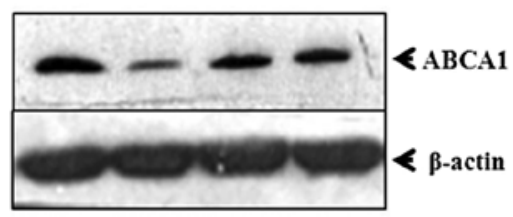

D

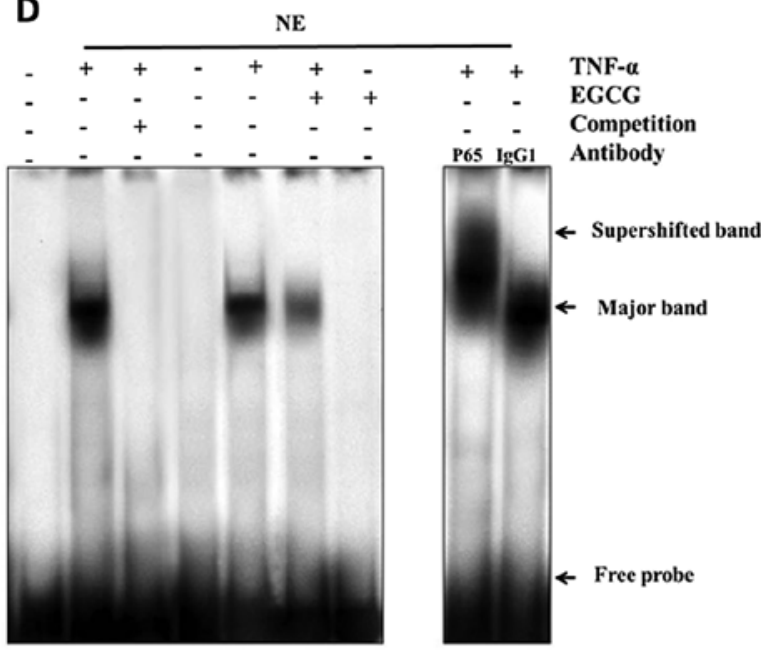

Figure 3. EGCG prevents TNF- $\alpha$-induced NF- $\kappa$ B activation. (A) Macrophage cells were incubated for $18 \mathrm{~h}$ with or without TNF- $\alpha$ and inhibitors of the NF- $\kappa \mathrm{B}$ pathway AICAR $(0.5 \mathrm{mM})$ or metformin $(1 \mathrm{mM})$. Following cell incubation, ABCA1 mRNA levels were examined by quantitative RT-PCRs. (B and C) ABCA1 protein levels were examined by western blot analysis. Values for each treatment represent a mean $\pm \mathrm{SE}$ of three individual wells. ${ }^{*}<0.05$ vs. control (D) Macrophage cells were treated or untreated with $40 \mu \mathrm{g} / \mathrm{Ml}$ of EGCG for $16 \mathrm{~h}$ before stimulated with $10 \mathrm{ng} / \mathrm{ml}$ of TNF- $\alpha$ for $2 \mathrm{~h}$. Autoradiography of EMSA was performed with a ${ }^{32} \mathrm{P}$-labeled NF- $\kappa \mathrm{B}$ nucleotide and nuclear protein extracts (NEs) from macrophage cells. Two specific band complexes, based on competition with a molar excess of unlabeled probe, are shown in the assays. A supershift analysis was performed by incubating the NEs with a specific antibody against the detected band complexes.

effects of EGCG was markedly, but not totally, abrogated. The measure of ABCA1 protein levels (Fig. 4H and I) and promoter activities (Fig. 4J) came up with similar results in which the effects of EGCG were completely abrogated by 67LR knockdown, but not Nrf2 knockdown. These results have confirmed that $67 \mathrm{LR}$, as the receptor of EGCG, is involved in the mechanism of EGCG regulation. In addition, these data suggest that the enhancement of nuclear Nrf2 level is probably a major, but not the only, mechanism contributing to the effects of EGCG.

Previous studies have reported that Keap1 represses $\mathrm{NF}-\kappa \mathrm{B}$ function by inducing IKK $\beta$ degradation $(33,34)$. Therefore, we tested the function of Keap 1 involved in the effects of EGCG. First, the effects of EGCG and/or TNF- $\alpha$ at Keap1 protein levels were measured. Protein mass of Keap1 in cells exposed to TNF- $\alpha$ or pretreatment with EGCG was not altered (Fig. 5A and B). Consequently, cells were transfected with Keap1 siRNA and the transfected effects were shown in Fig. 5C and D. When compared with 67LR knockdown, no significant alteration was found in Keap1 and Nrf2 double knockdown experiments. With Keap1 knocked down in the cells, the NF- $\kappa \mathrm{B}$ transcriptional activity was modestly, but significantly, enhanced in our experiments (Fig. 5E and F). Moreover, the knockdown of Keap1 also attenuated the effects of EGCG on upregulated ABCA1 (Fig. 5G, H and I). Furthermore, the protein levels of IKK $\beta$ were measured in these cells. When compared with the controls, cell exposure to TNF- $\alpha$ caused a significant increase in IKK $\beta$ protein levels, which were reduced by pretreatment with EGCG, and these reduced effects of EGCG were abrogated by Keap1 knockdown in these cells (Fig. 5J and K). These results further confirmed that EGCG inhibited the $\mathrm{NF}-\kappa \mathrm{B}$ transcriptional activity for downregulation of ABCA1, which were originally induced by TNF- $\alpha$, partially through the Keap1-induced IKK $\beta$ degradation.

\section{Discussion}

The present studies have demonstrated that THP-1 macrophage-derived foam cell exposure to $\mathrm{TNF}-\alpha$ results in downregulation of ABCA1 gene expression and decrease in cholesterol efflux to apoA1, and these harmful effects could be attenuated by pretreatment with EGCG in these cells via inhibiting the $\mathrm{NF}-\kappa \mathrm{B}$ activities. In order to inhibit the TNF- $\alpha-$ induced NF- $\kappa \mathrm{B}$ activities, EGCG is mediated into cytoplasm by $67 \mathrm{LR}$ promoting the dissociation of the Nrf2-Keap1 complex. On the one hand, the released Nrf2 translocates to the nucleus and activates the transcription of genes containing 

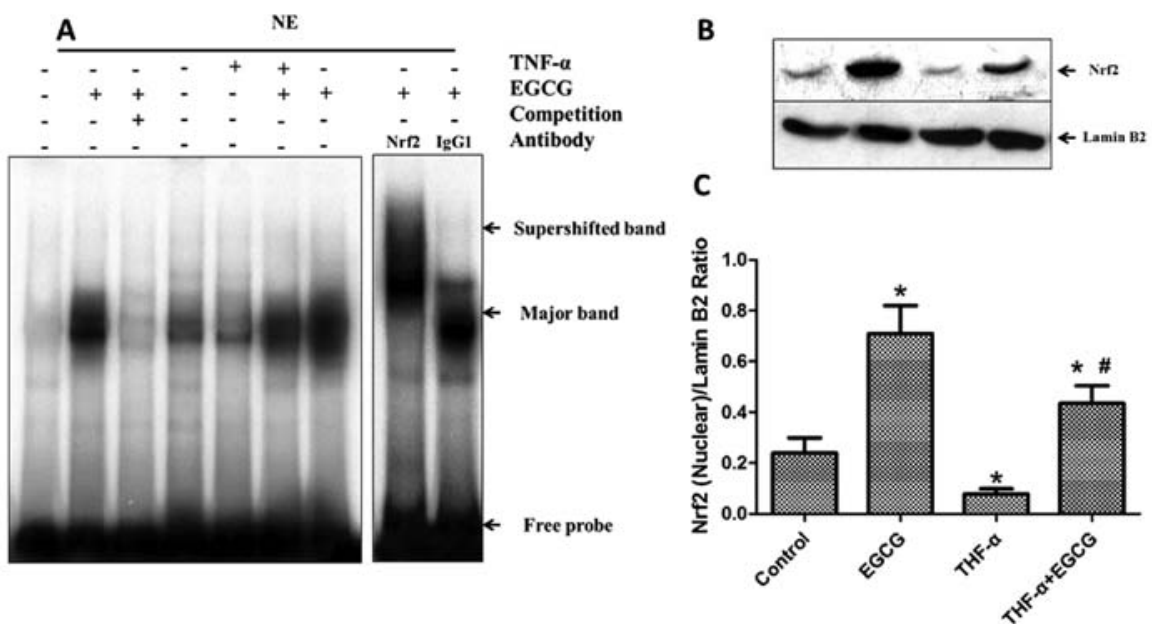

D

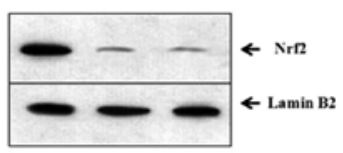

$\mathbf{F}$

H

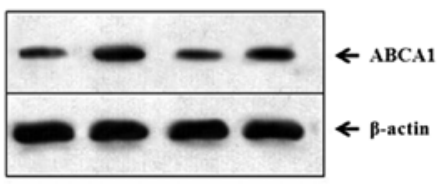

I

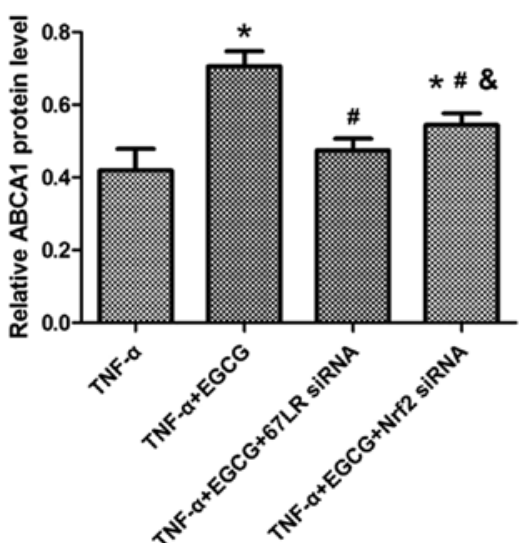

E

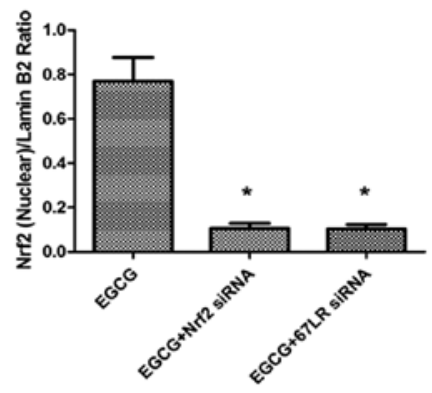

$\mathbf{G}$

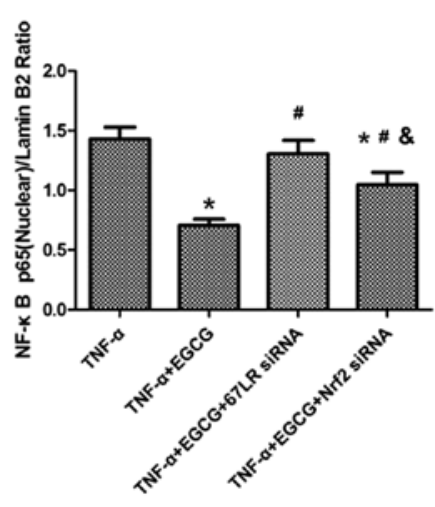

J

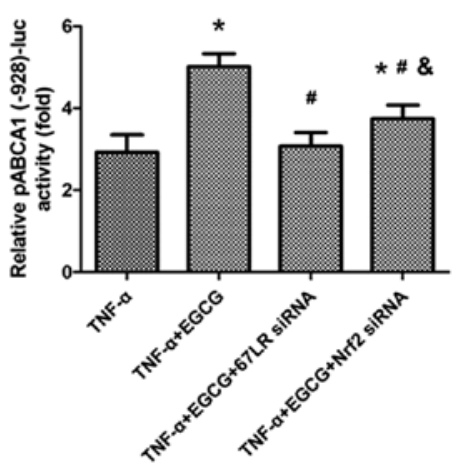

Figure 4. EGCG induces nuclear Nrf2 activation. (A) Macrophage cells were treated or untreated with $40 \mu \mathrm{g} / \mathrm{ml}$ of EGCG for $16 \mathrm{~h}$ before stimulated with $10 \mathrm{ng} / \mathrm{ml}$ of TNF- $\alpha$ for $2 \mathrm{~h}$. Autoradiography of EMSA was performed with a ${ }^{32} \mathrm{P}$-labeled human NQO1 ARE sequence and nuclear protein extracts (NEs). Two specific band complexes, based on competition with a molar excess of unlabeled probe, are shown in the assays. A supershift analysis was performed by incubating the NEs with a specific antibody against the detected band complexes. (B and C) Macrophage cells were incubated with EGCG and/or TNF- $\alpha$ for $18 \mathrm{~h}$. Following cell incubation, nuclear Nrf2 protein levels were examined by western blot analysis. (D and E) Macrophage cells were transfected with 67LR siRNA and Nrf2 siRNA by using Lipofectamine for $24 \mathrm{~h}$. After transfection, these cells were treated with EGCG. Then, transfection effects were detected by western blot analysis. (F and G) Protein levels of NF- $\mathrm{KB}$ p65 in nuclear extracts were measured and analyzed. (H and I) Promoter activities of the gene construct pABCA1(-928)-luc were also analyzed following cell incubation. (J) ABCA1 protein levels were measured by western blot analysis. Data are means \pm SE (repeated experiments; $n=3$ ). ${ }^{*} \mathrm{P}<0.05$ vs. control; " $\mathrm{P}<0.05$ vs. TNF- $\alpha$; and $\mathrm{P}<0.05$ vs. TNF- $\alpha+\mathrm{EGCG}+67$ LR siRNA. 
A

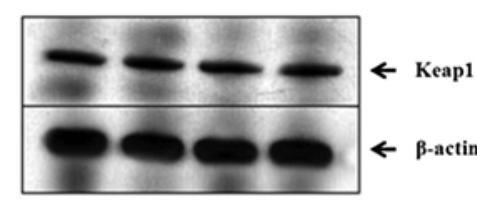

B

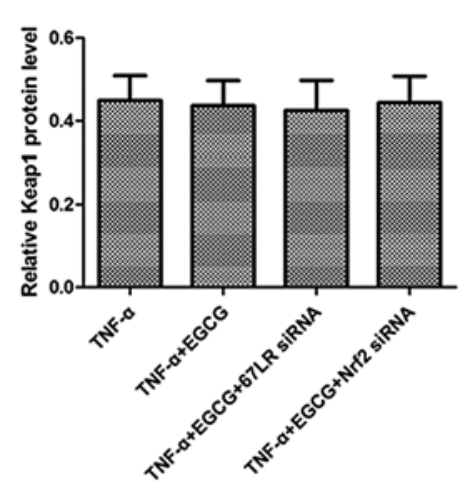

C

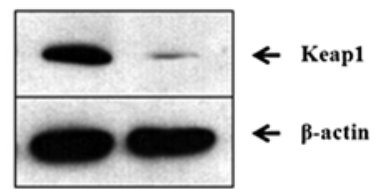

D

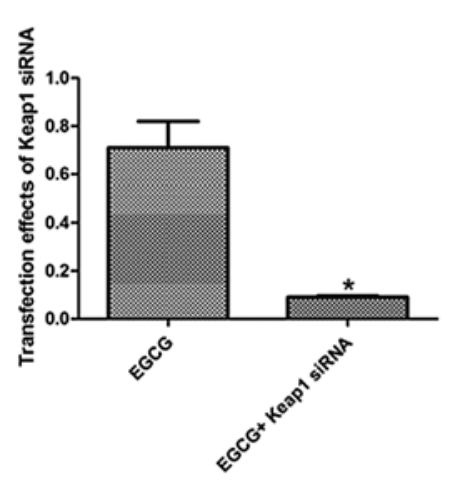

E

F
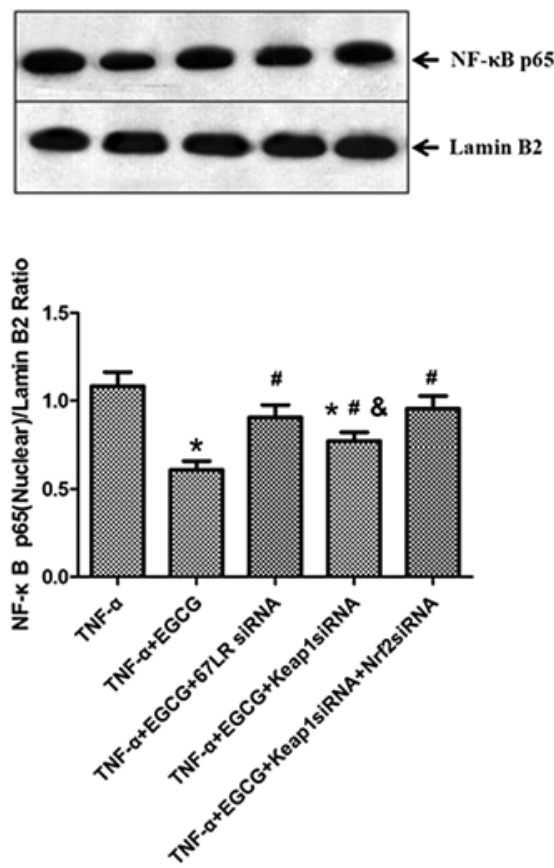

G

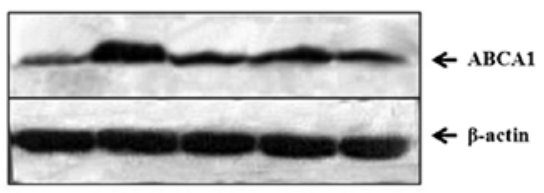

J
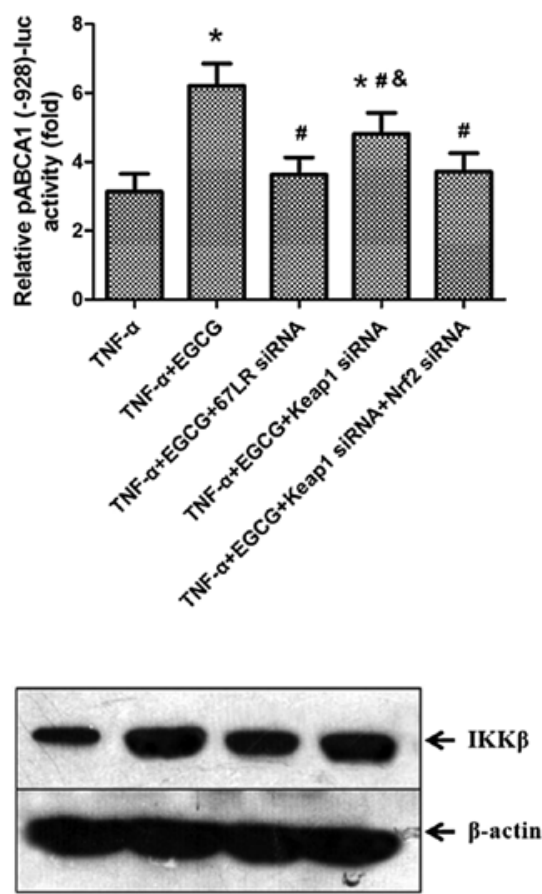

H

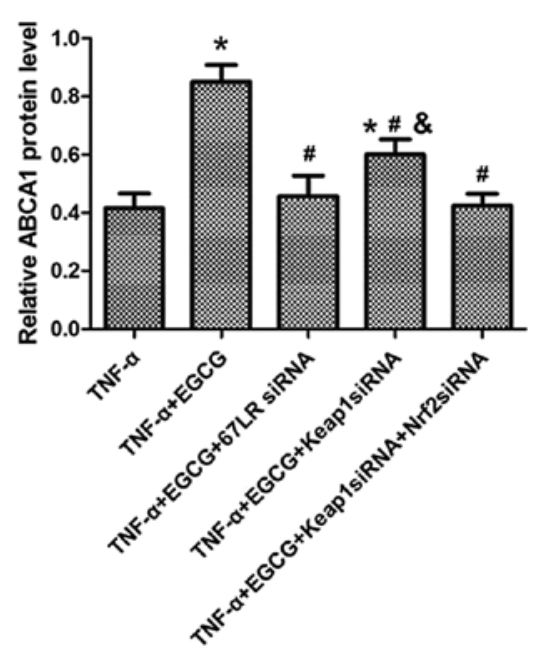

k

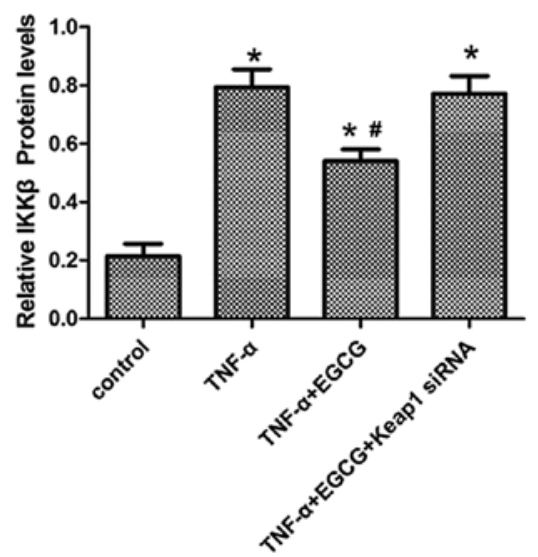

Figure 5. Keap1-induced IKK $\beta$ degradation is involved in the regulatory effects of EGCG. (A and B) Macrophage cells were incubated with EGCG and/or TNF- $\alpha$ for 18 h. Following cell incubation, protein mass of Keapl was measured by western blot analyses. (C and D) Macrophage cells were transfected with Keap1 siRNA by using Lipofectamine for $24 \mathrm{~h}$. After transfection, transfection effects of the cells were detected by western blot analysis. (E and F) These transfected cells were then treated with EGCG and/or TNF- $\alpha$. Cells were lysed and protein levels were analyzed with western blot analysis. Protein levels of p65 in nuclear extracts were measured and shown. (G and H) ABCA1 protein levels were measured and analyzed with western blot analysis. (I) Promoter activities of the gene construct pABCA1(-928)-luc were also examined following cell incubation. ( $\mathrm{J}$ and $\mathrm{K}$ ) IKK $\beta$ protein levels were measured and analyzed. Data are the means $\pm \mathrm{SE}$ (repeated experiments; $\mathrm{n}=3$ ). ${ }^{*} \mathrm{P}<0.05$ vs. control; ${ }^{*} \mathrm{P}<0.05$ vs. TNF- $\alpha$; and $\mathrm{P}<0.05$ vs. TNF- $\alpha+\mathrm{EGCG}+67 \mathrm{LR}$ siRNA. 


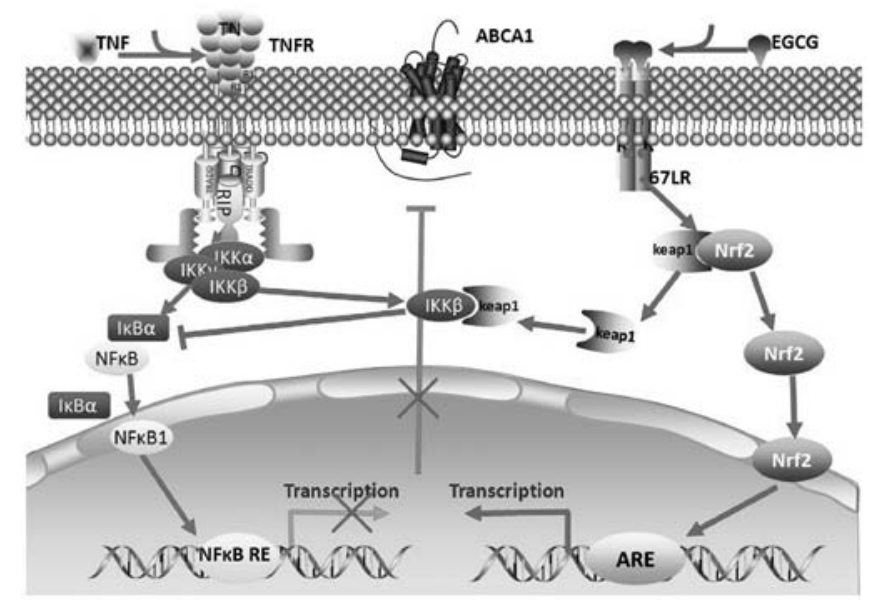

Figure 6. EGCG prevents TNF- $\alpha$-induced NF- $\kappa B$ activation thereby upregulating ABCA1 in THP-1 macrophage-derived foam cells via Nrf2/Keap1 pathway. Macrophage cell exposure to TNF- $\alpha$ results in a downregulation of ABCA1 gene expression and a decrease in cholesterol efflux to apoA1, which, however, is attenuated by pretreatment with EGCG in these cells Rather than activating the LXR pathway, inhibiting the TNF- $\alpha$-induced $\mathrm{NF}-\kappa \mathrm{B}$ activities is involved in the upregulatory effect of EGCG on ABCA1. To inhibit the TNF- $\alpha$-induced NF- $\kappa B$ activities, EGCG are mediated into cytoplasm by 67LR promoting the dissociation of the Nrf2-Keap1 complex. On the one hand, the released Nrf2 translocates to the nucleus and, in combination with other transcription factors, activates the transcription of genes containing an ARE element in their promoter regions resulting in inhibition effect on TNF- $\alpha$-induced NF- $\kappa$ B activities. On the other hand, Keap1 is separated from Nrf2-Keap1 complex and directly interacts with IKK $\beta$ and represses NF-kB function.

an ARE element in their promoter regions leading to inhibition of TNF- $\alpha$-induced NF- $\kappa$ B activities. On the other side, Keapl is separated from Nrf2-Keap1 complex and directly interacts with IKK $\beta$ and represses NF-KB function (Fig. 6).

Previous studies have provided evidence suggesting that one of the cholesterol-lowering effects of green tea is mainly elicited by EGCG $(35,36)$. One of the underlying mechanisms by which EGCG affects cholesterol metabolism is by interfering with the micellar solubilization of cholesterol in the digestive tract, which then in turn decreases cholesterol absorption (35). Also EGCG, through significantly increasing the reduced activity of lecithin cholesterol acyl transferase (LCAT), can reduce the levels of serum low-density lipoprotein (LDL) cholesterol and very low-density lipoprotein (VLDL) cholesterol and increases serum HDL-cholesterol in myocardial-infarcted rats (37). These recent studies have also indicated that EGCG improves cholesterol metabolism through the upregulation of LDL receptor and also reduces extracellular apoB levels (38). In addition, sterol regulatory element-binding proteins-1c (SREBP-1c), C/EBP- $\beta$, and peroxisome proliferator-activated receptor- $\gamma$ (PPAR- $\gamma$ ), also are involved in the cholesterol-lowering effect of EGCG $(39,40)$. However, effects of EGCG on ABCA1, which plays a key role in the process of RCT, have rarely been described until now. In the present studies, we have demonstrated that EGCG increases the expression of ABCA1 and facilitates the cholesterol efflux to apoA1 in the TNF- $\alpha$-induced inflammatory effects on THP-1 macrophage-derived foam cells. Nevertheless, no effects of EGCG on ABCA1 are found in the cells without exposure to TNF- $\alpha$. These results suggest that
EGCG has an indirect effect on ABCA1 under an inflammatory pathological condition.

In the macrophages, targeting LXR activation is believed to enhance the expression of ABCA1 and remove cholesterol from the cells (10-12). Our prior results in THP-1 macrophage cell lines also support this notion $(11,12,31,41)$. Therefore, targeting LXR may be related to the effect of EGCG on ABCA1 in TNF- $\alpha$-induced inflammatory cells. Interestingly, in the present studies, no mRNA levels or protein levels of LXR- $\alpha / \beta$ were altered in our experiments. The deletion of the DR4 element from the promoter of ABCA1 did not reverse the effects of EGCG. Interesting results were also found in another study on 3T3-L1 cells in which EGCG was found to greatly decrease the expression of PPAR- $\gamma 2$ and LXR- $\alpha$ (42). Different results were reported in that study possibly due to the different types of cell lines, which, however, at the very least, indicates that EGCG has no effects on upregulation of LXR. Thus, all these results infer that an LXR-independent mechanism is preferred.

A large body of evidence indicates that EGCG reversed lipid anomalies along with attenuating the inflammation $(43,44)$. Is there any relationship between the two functions of EGCG? In the human intestinal cell line Caco-2, TNF- $\alpha$ decreases ABCA1 expression and attenuates HDL cholesterol efflux, whereas inhibitors of the NF- $\kappa B$ pathway attenuate the effect of TNF- $\alpha$ on ABCA1 expression (14). Inhibition of NF- $\mathrm{KB}$ activities is believed to block the TNF- $\alpha$-induced inflammation (45). Therefore, NF- $\mathrm{kB}$ pathway may be a link between the two EGCG functions, anti-inflammation and improved cholesterol metabolism. In addition, because of the promoter of ABCA1 containing an NF- $\mathrm{KB}$ binding site (46), the mechanism possibly is that EGCG indirectly affects $A B C A 1$ via suppressing the binding of $A B C A 1$ promoter and NF- $\mathrm{KB}$. The results of our studies have further confirmed the notion. Macrophage cell exposure to TNF- $\alpha$ enhances NF- $\kappa B$ DNA-binding activity, whereas pretreatment with EGCG then results in a marked reduction in binding.

To further examine the involvement of important cellular components in cell fate, we focused first on Nrf2 based on the facts that EGCG activates it $(18,28,29)$. EGCG has been reported to have anti-inflammatory effects by increasing nuclear Nrf2 activities and inhibiting nuclear NF-kB-mediated inflammatory responses in vivo (29). Our current studies showed that TNF- $\alpha$ caused an activity of NF- $\mathrm{KB}$ pathway resulting in inflammatory injury. Therefore, it is plausible that we can cope with the harmful effects of TNF- $\alpha$ through induction of Nrf2. In the present study, we observed that cells exposed to TNF- $\alpha$ attenuated the Nrf2 DNA-binding activity, which, however, was specially reversed by pretreatment with EGCG. Western blot analysis data also showed that EGCG decreased cytosolic protein levels and enhanced cellular nuclear Nrf2 protein levels in THP-1 macrophage cell lines, which was in agreement with the results of studies in rats with pulmonary fibrosis and rats with lupus nephritis $(28,29)$. Thus, it is clear that EGCG induces the cytosolic Nrf2 translocation to the nucleus and activates the transcription of genes containing an ARE element in their promoter regions resulting in inhibition of TNF- $\alpha$-induced NF- $\mathrm{KB}$ activity. Considering previous studies showing that mitogen-activated protein kinases (MAPKs) play a role in potentiating Nrf2-mediated ARE 
activation and modulating $\mathrm{NF}-\kappa \mathrm{B}, \mathrm{MAPKs}$ were reported to be involved in regulatory network of $\mathrm{Nrf} 2$ and $\mathrm{NF}-\kappa \mathrm{B}(30,47)$. However, the detailed regulatory network of $\mathrm{Nrf} 2$ and $\mathrm{NF}-\kappa \mathrm{B}$ is still unknown and further study is necessary.

In order to further demonstrate the notion that induction of Nrf2 is the special molecule involved in regulatory mechanism of EGCG, cells were transfected with Nrf2 siRNA for gene knockdown in the present studies. Interestingly, the effects of EGCG on NF- $\mathrm{BB}$ and ABCA1 were marked, but not totally abrogated by silencing the Nrf2. It is possible that another regulatory mechanisms contribute to the effects of EGCG. Nrf2 is a major target degraded by Keap1, which was also reported to repress $N F-\kappa B$ function by inducing IKK $\beta$ degradation $(33,34)$, we questioned whether the $N F-\kappa B$ inhibitive function of EGCG might be related partially to Keap1. Consequently, our results have confirmed the hypothesis. Knockdown of Keap1 attenuated the effects of EGCG, and the levels of IKK $\beta$ proteins were also altered in the presence or the absence of Keap1. Thus, EGCG attenuates the $\mathrm{NF}-\kappa \mathrm{B}$ transcriptional activity and downregulation of ABCA1, which were induced by TNF- $\alpha$, partially through the Keap1-induced IKK $\beta$ degradation in THP-1 macrophage cell lines. During this period, Keap1 functions as a CUL3based E3 ligase of IKK $\beta$ and induce IKK $\beta$ ubiquitination (33). A similar conclusion was obtained recently by others that Keap1 is involved in the negative regulation of $N F-\kappa B$ signaling through the inhibition of IKK $\beta$ phosphorylation and the mediation of autophagy-dependent IKK $\beta$ degradation (34). Of interest, this effect of Keap1 on IKK $\beta$ was confirmed to exist only in human, chimpanzee, and dog and not in rat or mouse (33).

In the present studies, it is clear that EGCG plays its effects through promoting the dissociation of Nrf2 from Keap1, yet whether EGCG directly interacted with Nrf2 or Keap1 resulting in the dissociation is still unclear. In view of other previous studies, one possibility is that electrophiles of EGCG acting as a phase 2 enzyme inducers directly interact with the highly reactive cysteine residues of Keap1 thereby causing conformational changes of this repressor protein, which abrogates the capability of Keap1 to aid proteasomal degradation of Nrf2 (48-52). It is also plausible that reactive forms of EGCG conjugate with GSH, a most abundant endogenous antioxidant in eukaryotic cells and a major player in the regulation of the cellular redox state, thereby reducing the level of cellular GSH, which may result in transient disruption of redox-status with concomitant activation of MAPK cascades triggering Nrf2 phosphorylation (53-56). Therefore, further studies are required to more specifically address these possibilities.

In conclusion, the present study outlines, under a TNF- $\alpha$ induced inflammatory pathological condition, a previously unrecognized role for EGCG and Nrf2/Keap1 pathway in the regulation of ABCA1 expression and cholesterol efflux in THP-1 macrophage-derived foam cells. Furthermore, although more detailed mechanisms remained to be further elucidated, the investigation of Nrf2/Keap1 pathway has provided important basic insights into the anti-inflammatory effects of EGCG, as well as the identification of a novel potential therapeutic role for prevention of atherosclerosis.

\section{Acknowledgements}

The authors gratefully acknowledge the financial support from the National Natural Sciences Foundation of China (81170278, 81070220), the Heng Yang Joint Funds of Hunan Provincial Natural Sciences Foundation of China (10JJ9019), and the Aid Program for Science and Techology Innovative Research Team in Higher Educational Institutions (2008-244) of Human Province, China.

\section{References}

1. Hansson GK: Inflammation, atherosclerosis, and coronary artery disease. N Engl J Med 352: 1685-1695, 2005.

2. Kolodgie FD, Gold HK and Burke AP, et al: Intraplaque hemorrhage and progression of coronary atheroma. N Engl J Med 349: 2316-2325, 2003.

3. Khovidhunkit W, Kim MS and Memon RA, et al: Effects of infection and inflammation on lipid and lipoprotein metabolism: mechanisms and consequences to the host. J Lipid Res 45: 1169-1196, 2004.

4. Yin K, Liao DF and Tang CK: ATP-binding membrane cassette transporter A1 (ABCA1): a possible link between inflammation and reverse cholesterol transport. Mol Med 16: 438-449, 2010.

5. von Eckardstein A, Nofer JR and Assmann G: High density lipoproteins and arteriosclerosis. Role of cholesterol efflux and reverse cholesterol transport. Arterioscler Thromb Vasc Biol 21: 13-27, 2001.

6. Zhao GJ, Yin K, Fu YC and Tang CK: The interaction of ApoA-I and $\mathrm{ABCA} 1$ triggers signal transduction pathways to mediate efflux of cellular lipids. Mol Med: Nov 2, 2011 (Epub ahead of print). doi: 10.2119/molmed.2011.00183.

7. Yin K, Deng X and Mo ZC, et al: Tristetraprolin-dependent post-transcriptional regulation of inflammatory cytokine mRNA expression by apolipoprotein A-I: role of ATP-binding membrane cassette transporter A1 and signal transducer and activator of transcription 3. J Biol Chem 286: 13834-13845, 2011.

8. Liu XH, Xiao J and Mo ZC, et al: Contribution of D4-F to ABCA1 expression and cholesterol efflux in THP-1 macrophagederived foam cells. J Cardiovasc Pharmacol 56: 309-319, 2010.

9. Berge KE, Tian H and Graf GA, et al: Accumulation of dietary cholesterol in sitosterolemia caused by mutations in adjacent ABC transporters. Science 290: 1771-1775, 2000.

10. Repa JJ, Turley SD and Lobaccaro JA, et al: Regulation of absorption and $\mathrm{ABC} 1$-mediated efflux of cholesterol by RXR heterodimers. Science 289: 1524-1529, 2000.

11. Hao XR, Cao DL and $\mathrm{Hu}$ YW, et al: IFN-gamma downregulates ABCA1 expression by inhibiting LXRalpha in a JAK/STAT signaling pathway-dependent manner. Atherosclerosis 203: 417-428, 2009.

12. Dai XY, Ou X and Hao XR, et al: The effect of T0901317 on ATP-binding cassette transporter A1 and Niemann-Pick type C1 in apoE-/-mice. J Cardiovasc Pharmacol 51: 467-475, 2008.

13. Chen M, Li W, Wang N, Zhu Y and Wang X: ROS and NF-kappaB but not LXR mediate IL-1beta signaling for the downregulation of ATP-binding cassette transporter A1. Am J Physiol Cell Physiol 292: C1493-C1501, 2007.

14. Field FJ, Watt K and Mathur SN: TNF-alpha decreases ABCA1 expression and attenuates HDL cholesterol efflux in the human intestinal cell line Caco-2. J Lipid Res 51: 1407-1415, 2010.

15. Zhu X, Owen JS and Wilson MD, et al: Macrophage ABCA1 reduces MyD88-dependent Toll-like receptor trafficking to lipid rafts by reduction of lipid raft cholesterol. J Lipid Res 51: 3196-3206, 2010.

16. Barroso E, Eyre E, Palomer X and Vazquez-Carrera M: The peroxisome proliferator-activated receptor beta/delta (PPARbeta/delta) agonist GW501516 prevents TNF-alpha-induced NF-kappaB activation in human $\mathrm{HaCaT}$ cells by reducing p65 acetylation through AMPK and SIRT1. Biochem Pharmacol 81: 534-543, 2011.

17. Lee SJ, Lee IS and Mar W: Inhibition of inducible nitric oxide synthase and cyclooxygenase-2 activity by $1,2,3,4,6$-penta-Ogalloyl-beta-D-glucose in murine macrophage cells. Arch Pharm Res 26: 832-839, 2003.

18. Yuan JH,Li YQ and Yang XY: Inhibition of epigallocatechin gallate on orthotopic colon cancer by upregulating the Nrf2-UGT1A signal pathway in nude mice. Pharmacology 80: 269-278, 2007. 
19. Butt MS and Sultan MT: Green tea: nature's defense against malignancies. Crit Rev Food Sci Nutr 49: 463-473, 2009.

20. Wang P, Henning SM and Heber D: Limitations of MTT and MTS-based assays for measurement of antiproliferative activity of green tea polyphenols. PLoS One 5: e10202, 2010.

21. Cavet ME, Harrington KL, Vollmer TR, Ward KW and Zhang JZ: Anti-inflammatory and anti-oxidative effects of the green tea polyphenol epigallocatechin gallate in human corneal epithelial cells. Mol Vis 17: 533-542, 2011.

22. Umeda D, Tachibana H and Yamada K: Epigallocatechin-3-Ogallate disrupts stress fibers and the contractile ring by reducing myosin regulatory light chain phosphorylation mediated through the target molecule $67 \mathrm{kDa}$ laminin receptor. Biochem Biophys Res Commun 333: 628-635, 2005.

23. Hsieh CF, Tsuei YW and Liu CW, et al: Green tea epigallocatechin gallate inhibits insulin stimulation of adipocyte glucose uptake via the 67-kilodalton laminin receptor and AMP-activated protein kinase pathways. Planta Med 76: 1694-1698, 2010.

24. $\mathrm{Ku} \mathrm{HC}$, Chang $\mathrm{HH}$ and Liu HC, et al: Green tea (-)-epigallocatechin gallate inhibits insulin stimulation of 3T3-L1 preadipocyte mitogenesis via the 67-kDa laminin receptor pathway. Am J Physiol Cell Physiol 297: C121-C132, 2009.

25. Byun EH, Omura T, Yamada K and Tachibana H: Green tea polyphenol epigallocatechin-3-gallate inhibits TLR2 signaling induced by peptidoglycan through the polyphenol sensing molecule $67-\mathrm{kDa}$ laminin receptor. FEBS Lett 585: 814-820, 2011.

26. Zheng Y, Morris A, Sunkara M, Layne J, Toborek M and Hennig B Epigallocatechin-gallate stimulates NF-E2-related factor and heme oxygenase-1 via caveolin-1 displacement. J Nutr Biochem 23: 163-168, 2011.

27. Peng N, Liu JT, Guo F and Li R: Epigallocatechin-3-gallate inhibits interleukin-6- and angiotensin II-induced production of C-reactive protein in vascular smooth muscle cells. Life Sci 86: 410-415, 2010

28. Sriram N, Kalayarasan S and Sudhandiran G: Epigallocatechin3 -gallate augments antioxidant activities and inhibits inflammation during bleomycin-induced experimental pulmonary fibrosis through Nrf2-Keap1 signaling. Pulm Pharmacol Ther 22: 221-236, 2009

29. Tsai PY, Ka SM and Chang JM, et al: Epigallocatechin-3-gallate prevents lupus nephritis development in mice via enhancing the Nrf2 antioxidant pathway and inhibiting NLRP3 inflammasome activation. Free Radic Biol Med 51: 744-754, 2011.

30. Nair S, Doh ST, Chan JY, Kong AN and Cai L: Regulatory potential for concerted modulation of Nrf2- and Nfkb1-mediated gene expression in inflammation and carcinogenesis. Br J Cancer 99: 2070-2082, 2008

31. Chen SG, Xiao J and Liu XH, et al: Ibrolipim increases ABCA1/G1 expression by the LXRalpha signaling pathway in THP-1 macrophage-derived foam cells. Acta Pharmacol Sin 31 1343-1349, 2010.

32. Mo ZC, Xiao J and Liu XH, et al: AOPPs inhibits cholesterol efflux by downregulating ABCA1 expression in a JAK/STAT signaling pathway-dependent manner. J Atheroscler Thromb 18 : 796-807, 2011

33. Lee DF, Kuo HP and Liu M, et al: KEAP1 E3 ligase-mediated downregulation of NF-kappaB signaling by targeting IKKbeta. Mol Cell 36: 131-140, 2009.

34. Kim JE, You DJ, Lee C, Ahn C, Seong JY and Hwang JI: Suppression of NF-kappaB signaling by KEAP1 regulation of IKKbeta activity through autophagic degradation and inhibition of phosphorylation. Cell Signal 22: 1645-1654, 2010.

35. Raederstorff DG, Schlachter MF, Elste V and Weber P: Effect of EGCG on lipid absorption and plasma lipid levels in rats. J Nutr Biochem 14: 326-332, 2003.

36. Hsu CH, Tsai TH, Kao YH, Hwang KC, Tseng TY and Chou P Effect of green tea extract on obese women: a randomized, doubleblind, placebo-controlled clinical trial. Clin Nutr 27: 363-370, 2008.

37. Devika PT and Stanely MPP: Preventive effect of (-)epigallocatechin gallate on lipids, lipoproteins, and enzymes of lipid metabolism in isoproterenol-induced myocardial infarction in rats. J Biochem Mol Toxicol 23: 387-393, 2009.
38. Goto T, Saito Y, Morikawa K, Kanamaru Y and Nagaoka S: Epigallocatechin gallate changes mRNA expression level of genes involved in cholesterol metabolism in hepatocytes. Br J Nutr 19: $1-5,2011$.

39. Chen N, Bezzina R and Hinch E, et al: Green tea, black tea, and epigallocatechin modify body composition, improve glucose tolerance, and differentially alter metabolic gene expression in rats fed a high-fat diet. Nutr Res 29: 784-793, 2009.

40. Sohle J, Knott A and Holtzmann U, et al: White Tea extract induces lipolytic activity and inhibits adipogenesis in human subcutaneous (pre)-adipocytes. Nutr Metab (Lond) 6: 20, 2009.

41. Tang CK, Yi GH and Yang JH, et al: Oxidized LDL upregulated ATP binding cassette transporter-1 in THP-1 macrophages. Acta Pharmacol Sin 25: 581-586, 2004.

42. Moon HS, Chung CS, Lee HG, Kim TG, Choi YJ and Cho CS Inhibitory effect of (-)-epigallocatechin-3-gallate on lipid accumulation of 3T3-L1 cells. Obesity (Silver Spring) 15: 2571-2582, 2007.

43. Senthil KV, Arulmathi K, Sundarapandiyan R and Kalaiselvi P: Attenuation of the inflammatory changes and lipid anomalies by epigallocatechin-3-gallate in hypercholesterolemic diet fed aged rats. Exp Gerontol 44: 745-751, 2009.

44. Bose M, Lambert JD, Ju J, Reuhl KR, Shapses SA and Yang CS: The major green tea polyphenol, (-)-epigallocatechin-3-gallate, inhibits obesity, metabolic syndrome, and fatty liver disease in high-fat-fed mice. J Nutr 138: 1677-1683, 2008

45. Lee AS, Jung YJ and Kim DH, et al: Epigallocatechin-3-Ogallate decreases tumor necrosis factor-alpha-induced fractalkine expression in endothelial cells by suppressing NF-kappaB. Cell Physiol Biochem 24: 503-510, 2009.

46. Santamarina-Fojo S, Peterson K and Knapper C, et al: Complete genomic sequence of the human ABCA1 gene: analysis of the human and mouse ATP-binding cassette A promoter. Proc Natl Acad Sci USA 97: 7987-7992, 2000.

47. Kong AN, Owuor E and Yu R, et al: Induction of xenobiotic enzymes by the MAP kinase pathway and the antioxidant or electrophile response element (ARE/EpRE). Drug Metab Rev 33: 255-271, 2001.

48. Yamamoto T, Suzuki T and Kobayashi A, et al: Physiological significance of reactive cysteine residues of Keapl in determining Nrf2 activity. Mol Cell Biol 28: 2758-2770, 2008.

49. Copple IM, Goldring CE, Kitteringham NR and Park BK: The Nrf2-Keap1 defence pathway: role in protection against druginduced toxicity. Toxicology 246: 24-33, 2008

50. Eggler AL, Gay KA and Mesecar AD: Molecular mechanisms of natural products in chemoprevention: induction of cytoprotective enzymes by Nrf2. Mol Nutr Food Res 52 (Suppl 1): S84-S94, 2008.

51. Eggler AL, Liu G, Pezzuto JM, van Breemen RB and Mesecar AD: Modifying specific cysteines of the electrophile-sensing human Keap1 protein is insufficient to disrupt binding to the Nrf2 domain Neh2. Proc Natl Acad Sci USA 102: 10070-10075, 2005.

52. Jain AK, Mahajan S and Jaiswal AK: Phosphorylation and dephosphorylation of tyrosine 141 regulate stability and degradation of INrf2: a novel mechanism in Nrf2 activation. J Biol Chem 283: 17712-17720, 2008.

53. Wu G, Fang YZ, Yang S, Lupton JR and Turner ND: Glutathione metabolism and its implications for health. J Nutr 134: 489-492, 2004.

54. Na HK and Surh YJ: Modulation of Nrf2-mediated antioxidant and detoxifying enzyme induction by the green tea polyphenol EGCG. Food Chem Toxicol 46: 1271-1278, 2008.

55. Huang HC, Nguyen T and Pickett CB: Phosphorylation of Nrf2 at Ser-40 by protein kinase $C$ regulates antioxidant response element-mediated transcription. J Biol Chem 277: 42769-42774, 2002.

56. Salazar M, Rojo AI, Velasco D, de Sagarra RM and Cuadrado A: Glycogen synthase kinase-3beta inhibits the xenobiotic and antioxidant cell response by direct phosphorylation and nuclear exclusion of the transcription factor Nrf2. J Biol Chem 281: 14841-14851, 2006. 